\title{
Determinan Profitabilitas Bank Umum Terdaftar di Bursa Efek Indonesia
}

\author{
Bambang Sutrisno \\ Universitas Muhammadiyah Jakarta \\ bambang.sutrisno@umj.ac.id
}

\begin{abstract}
A lot of prior studies examined the determinants of banks' profitability, both in developed and developing countries. This paper aims to investigate factors affecting the profitability of 30 commercial banks listed on the Indonesia Stock Exchange (IDX) from 2012 to 2016. This study employs panel regression with annual data. The results reveal that the capital adequacy ratio, net interest margin, and gross domestic product have the positive and significant effect on return on assets. Operating expenses to operating revenues have the negative and significant impact on return on assets. The non-performing loan, loan to deposit ratio, and inflation do not affect return on assets.
\end{abstract}

Keywords: profitability, commercial banks, panel regression

\begin{abstract}
Abstrak
Banyak penelitian sebelumnya menguji determinan profitabilitas bank, baik di negara maju dan berkembang. Tulisan ini bertujuan untuk menginvestigasi faktor-faktor yang memengaruhi profitabilitas 30 bank umum terdaftar di Bursa Efek Indonesia (BEI) dari 2012 hingga 2016. Penelitian ini menggunakan regresi panel dengan data tahunan. Hasil penelitian menyatakan bahwa capital adequacy ratio, net interest margin, dan gross domestic product berpengaruh positif dan signifikan terhadap return on assets. Beban operasional terhadap pendapatan operasional berpengaruh negatif dan signifikan terhadap return on assets. Non performing loan, loan to deposit ratio, dan inflasi tidak memengaruhi return on assets.
\end{abstract}

Kata Kunci: profitabilitas, bank umu, regresi data panel

\section{Cara Mengutip:}

Sutrisno, B. (2018). Determinan Profitabilitas Bank Umum Terdaftar di Bursa Efek Indonesia. Esensi: Jurnal Bisnis dan Manajemen. Vol. 8 (1): 41 - 48. doi: 10.15408/ess.v8i1.6554. 


\section{PENDAHULUAN}

Sektor perbankan berperan penting bagi pertumbuhan perekonomian melalui fungsi intermediasinya. Sufian \& Chong (2008) menyatakan bahwa kinerja sektor perbankan berpengaruh signifikan terhadap pertumbuhan perekonomian. Salah satu satu ukuran kinerja sektor perbankan adalah profitabilitas. Profitabilitas merupakan kemampuan suatu perusahaan dalam menghasilkan laba pada periode tertentu (Hanafi \& Halim, 2016). Kajian akan faktor-faktor yang memengaruhi profitabilitas sektor perbankan menjadi sangat penting tidak hanya untuk manajer bank, tetapi juga untuk para pemangku kepentingan seperti bank sentral, asosiasi banker, pemerintah, dan masyarakat.

Tingkat profitabilitas bank dapat dipengaruhi oleh faktor internal dan eksternal. Penelitian-penelitian empiris sebelumnya telah menguji determinan profitabilitas bank, baik di negara maju maupun negara berkembang. Terdapat beberapa penelitian sebelumnya yang menguji determinan profitabilitas bank dari sisi faktor internal saja (Javaid dkk., 2011 dan Hayati \& Musdholifah, 2014). Namun terdapat juga beberapa penelitian yang menguji faktor internal dan eksternal terhadap profitabilitas bank (Kosmidou, 2008; Sufian \& Chong, 2008; Anbar \& Alper, 2011; dan Jeong \& Doyeon, 2013).

Tabel 1 dan 2 menyajikan perkembangan rasio keuangan bank umum dan variabel makroekonomi (GDP dan tingkat inflasi) pada tahun 2012-2016 di Indonesia. Kedua tabel menunjukkan bahwa setiap variabel berfluktuasi dari tahun ke tahun. Fakta ini mengindikasikan bahwa ada perbedaan antara hasil dan teori. Sebagai contoh, teori menyebutkan bahwa CAR berpengaruh positif terhadap ROA. Jika CAR meningkat, maka ROA meningkat pula. Tabel 1 menunjukkan bahwa CAR mengalami peningkatan dari tahun 2012 ke 2013. Namun ROA malah mengalami penurunan dari tahun 2012 ke 2013. Contoh lain misalnya menurut teori, GDP berpengaruh positif terhadap ROA. Tabel 2 memperlihatkan bahwa GDP meningkat dari tahun 2015 ke 2016, namun ROA menunjukkan penurunan dari tahun 2015 ke 2016. Adanya inkonsistensi hasil dengan teori mendorong penelitian ini menguji lebih lanjut akan pengaruh faktor internal dan eksternal terhadap profitabilitas bank.

Tabel 1 Perkembangan Rasio Keuangan Bank Umum di Indonesia Tahun 2012-2016

\begin{tabular}{lrrrrr}
\hline \multirow{2}{*}{ Rasio (\%) } & \multicolumn{5}{c}{ Tahun } \\
\cline { 2 - 6 } & $\mathbf{2 0 1 2}$ & $\mathbf{2 0 1 3}$ & $\mathbf{2 0 1 4}$ & $\mathbf{2 0 1 5}$ & $\mathbf{2 0 1 6}$ \\
\hline ROA & 3.13 & 3.08 & 2.85 & 2.32 & 2.23 \\
CAR & 17.46 & 18.59 & 19.57 & 21.39 & 22.93 \\
NPL & 3.45 & 3.78 & 4.12 & 3.84 & 5.39 \\
BOPO & 72.53 & 74.03 & 76.29 & 81.49 & 82.22 \\
LDR & 83.58 & 89.70 & 89.42 & 92.11 & 90.70 \\
NIM & 5.49 & 4.89 & 4.23 & 5.39 & 5.63 \\
\hline
\end{tabular}

Sumber: Statistik Perbankan Indonesia

Penelitian ini menguji faktor internal dan eksternal yang memengaruhi profitabilitas bank (return on assets/ROA). Faktor internal yang digunakan dalam penelitian ini adalah capital adequacy ratio (CAR), non performing loan (NPL), beban operasional terhadap 
pendapatan operasional (BOPO), loan to deposit ratio (LDR), dan net interest margin (NIM). Sedangkan faktor eksternal yang memengaruhi profitabilitas bank adalah gross domestic product (GDP), dan tingkat inflasi (INF).

Tabel 2 Perkembangan Variabel Makroekonomi di Indonesia Tahun 2012-2016

\begin{tabular}{lccccc}
\hline & \multicolumn{5}{c}{ Tahun } \\
\cline { 2 - 6 } Variabel Makroekonomi (\%) & $\mathbf{2 0 1 2}$ & $\mathbf{2 0 1 3}$ & $\mathbf{2 0 1 4}$ & $\mathbf{2 0 1 5}$ & $\mathbf{2 0 1 6}$ \\
\cline { 2 - 6 } GDP & 6.03 & 5.56 & 5.01 & 4.88 & 5.02 \\
INF & 4.28 & 6.41 & 6.39 & 6.36 & 3.53 \\
\hline
\end{tabular}

Sumber: World Bank Development Indicators

CAR merupakan ukuran dari jumlah modal bank yang dinyatakan dalam persentase aktiva tertimbang menurut risiko (ATMR). CAR yang tinggi dapat melindungi nasabah bank sehingga dapat meningkatkan kepercayaan nasabah terhadap bank. CAR yang tinggi menandakan bahwa bank tersebut mampu membiayai kegiatan operasional bank (Taswan, 2010). Semakin tinggi CAR menunjukkan bahwa bank tersebut semakin sehat permodalannya (Petria dkk., 2015). Selain itu, variabel lain yang akan dibahas dalam penelitian ini ialah tingkat pembiayaan bermasalah (non-performing loan/NPL). Semakin tinggi NPL menunjukkan bahwa semakin besar jumlah kredit bermasalah. Kondisi ini dapat menyebabkan suatu bank dalam kondisi bermasalah semakin besar. Apabila NPL sebuah bank tinggi, maka biaya pencadangan aktiva produktif dan biaya lainnya akan meningkat sehingga tingkat profitabilitas bank akan menurun, begitu pula sebaliknya.

BOPO menggambarkan efisiensi kegiatan operasional bank. BOPO yang semakin kecil mengindikasikan bahwa semakin efisien beban operasional yang dikeluarkan oleh bank sehingga kemungkinan suatu bank dalam kondisi bermasalah semakin kecil. Peningkatan beban operasional akan berdampak pada penurunan laba sebelum pajak dan pada akhirnya akan menurunkan profitabilitas bank (Petria dkk., 2015). Peningkatan BOPO menunjukkan inefisiensi bank dalam mengelola kegiatan operasionalnya dan dapat menurunkan laba.

LDR yang semakin tinggi dapat berakibat pada laba bank yang semakin meningkat (dengan asumsi bahwa bank tersebut dapat menyalurkan kredit secara efektif). Dengan meningkatnya laba bank, maka kinerja bank juga meningkat. Taswan (2010) mengungkapkan bahwa semakin besar LDR menandakan bahwa likuiditas bank semakin agresif, sebaliknya semakin kecil LDR mengindikasikan bahwa semakin besar dana pihak ketiga yang tidak digunakan untuk penempatan di kredit (banyak dana menganggur). Besar kecilnya LDR dapat memengaruhi kinerja bank.

Salah satu ukuran yang dapat digunakan untuk mengukur efisiensi bank adalah NIM. Taswan (2010) menyatakan bahwa semakin besar rasio NIM maka semakin baik kinerja bank dalam menghasilkan pendapatan bunga. Peningkatan pendapatan bunga berpengaruh positif terhadap laba bank yang ditunjukkan dengan peningkatan rasio ROA. NIM akan memengaruhi laba rugi bank yang pada akhirnya memengaruhi kinerja bank (Hayati \& Musdholifah, 2014).

GDP merupakan salah satu faktor eksternal yang umum digunakan sebagai indikator 
makroekonomi untuk mengukur kondisi perekonomian suatu negara dalam suatu periode tertentu. Tingkat pertumbuhan GDP diharapkan dapat berdampak pada sejumlah faktor sehubungan dengan permintaan dan penawaran akan simpanan dan pinjaman bank (Anbar \& Alper, 2011). Apabila GDP meningkat maka diasumsikan bahwa pendapatan dari masyarakat meningkat sehingga kemampuan masyarakat untuk menabung juga mengalami peningkatan. Penelitian sebelumnya yang menggunakan GDP sebagai salah satu faktor eksternal yang memengaruhi ROA adalah Sufian \& Chong (2008); Anbar \& Alper (2011); dan Lee \& Kim (2013). Indikator makroekonomi lain yang dapat memengaruhi kinerja bank adalah tingkat inflasi. Hubungan antara inflasi dan kinerja bank tergantung pada apakah inflasi diantisipasi atau tidak diantisipasi (Flamini dkk., 2009). Pada saat inflasi diantisipasi, bank dapat menyesuaikan suku bunga dari waktu ke waktu, yang hasilnya berdampak positif terhadap profitabilitas. Pada saat inflasi tidak diantisipasi, bank menyesuaikan suku bunganya dengan lambat dan menghasilkan biaya yang lebih cepat meningkat daripada pendapatan bank, hal ini berdampak negatif terhadap profitabilitas.

\section{METODE}

Pengambilan sampel dalam penelitian ini dipilih berdasarkan kriteria berikut: Pertama, bank umum yang secara konsisten terdaftar di Bursa Efek Indonesia pada kurun waktu tahun 2012-2016. Kedua, memiliki data yang lengkap selama periode penelitian. Penelitian ini menggunakan data sekunder dan berbasis tahunan. Data sekunder yang digunakan dalam penelitian ini meliputi laporan keuangan tahunan dari masing-masing bank umum, GDP, dan tingkat inflasi. Data laporan keuangan tahunan diperoleh dari website Otoritas Jasa Keuangan. Data GDP dan tingkat inflasi diperoleh dari World Bank Development Indicators (WDI).

Untuk menjawab tujuan dari penelitian ini yaitu untuk menganalisis determinan profitabilitas bank umum terdaftar di Bursa Efek Indonesia akan dipergunakan regresi panel. Adapun model penelitian yang digunakan dalam penelitian ini adalah:

$$
\begin{aligned}
R O A_{i t}=\alpha+ & \beta_{1} C A R_{i t}+\beta_{2} N P L_{i t}+\beta_{3} B O P O_{i t}+\beta_{4} L D R_{i t}+\beta_{5} N I M_{i t}+\beta_{6} G D P_{t} \\
& +\beta_{7} I N F_{t}+\varepsilon_{i t}
\end{aligned}
$$

dimana ROA adalah return on assets, CAR adalah capital adequacy ratio, NPL adalah non performing loan, BOPO adalah beban operasional terhadap pendapatan operasional, LDR adalah loan to deposit ratio, NIM adalah net interest margin, GDP adalah gross domestic product, INF adalah tingkat inflasi, dan $\varepsilon$ adalah error term.

Sebelum melakukan regresi panel, pemilihan metode estimasi terbaik perlu dilakukan terlebih dahulu. Uji Chow dan Hausman diterapkan untuk menentukan metode estimasi terbaik yang nantinya akan digunakan dalam analisis, apakah model pooled ordinary least square (PLS), model efek tetap (fixed effect), atau model efek random (random effect) (Nachrowi \& Usman, 2006). Uji Chow digunakan untuk memilih antara model PLS dengan model efek tetap. Sedangkan uji Hausman digunakan untuk memilih antara model efek tetap dengan model efek acak. Apabila nilai uji Hausman signifikan, maka model efek tetap lebih baik dibandingkan dengan model efek acak. 


\section{HASIL DAN PEMBAHASAN}

Tabel 3 menyajikan ringkasan statistik untuk semua variabel penelitian pada 30 bank umum terdaftar di Bursa Efek Indonesia yang menjadi sampel penelitian. Rata-rata ROA adalah sebesar $1.74 \%$ selama periode penelitian. Seluruh variabel independen memiliki ratarata positif. Adapun nilai rata-rata CAR, NPL, BOPO, LDR, NIM, GDP, dan INF masing-masing secara berurutan adalah 16.64\%, 2.83\%, 77.29\%, 73.98\%, 5.13\%, 5.30\%, dan 5.40\%.

Tabel 3. Statistik Deskriptif

\begin{tabular}{ccccc}
\hline Variabel & Mean & Min & Max & Std. Dev. \\
\hline ROA & 0.0174 & 0.0143 & 0.0693 & 0.0114 \\
CAR & 0.1664 & 0.0216 & 0.4649 & 0.0592 \\
NPL & 0.0283 & 0.0017 & 0.1916 & 0.0219 \\
BOPO & 0.7729 & 0.5993 & 0.9412 & 0.0919 \\
LDR & 0.7398 & 0.0290 & 1.1488 & 0.1623 \\
NIM & 0.0513 & 0.0117 & 0.1214 & 0.0181 \\
GDP & 0.0530 & 0.0488 & 0.0603 & 0.0049 \\
INF & 0.0540 & 0.0353 & 0.0641 & 0.0139 \\
\hline
\end{tabular}

Terdapat tiga metode estimasi yang dapat dipilih dalam analisis regresi panel yaitu pooled ordinary least square (PLS), model efek tetap (fixed effect), dan model efek random (random effect). Tabel 4 menyajikan hasil uji Chow dan Hausman untuk menentukan metode estimasi terbaik yang akan digunakan dalam penelitian. Tabel 4 menunjukkan bahwa hasil uji Chow dan Hausman, hasil uji dari kedua tes signifikan. Dengan kata lain, hipotesis nol dari uji Chow dan Hausman ditolak. Dengan demikian, metode estimasi terbaik yang dapat digunakan dalam penelitian ini adalah model efek tetap.

Tabel 4. Hasil Uji Chow dan Hausman

\begin{tabular}{ccc}
\hline Pemilihan Metode Estimasi Terbaik & Prob. & Kesimpulan \\
\hline Uji Chow & 0.0000 & Model Efek Tetap \\
Uji Hausman & 0.0000 & Model Efek Tetap \\
\hline
\end{tabular}

Hasil regresi panel dengan model efek tetap antara ROA dengan CAR, NPL, BOPO, LDR, NIM, GDP, dan INF disajikan dalam Tabel 5. Hasil penelitian menunjukkan bahwa CAR berpengaruh positif dan signifikan terhadap ROA pada tingkat $\alpha$ sebesar $1 \%$. Hubungan positif antara CAR dengan ROA mengindikasikan bahwa semakin baik permodalan suatu bank maka profitabilitas bank semakin meningkat pula. Temuan ini sejalan dengan Hayati \& Musdholifah (2014). 
Tabel 5. Hasil Regresi Panel

\begin{tabular}{ccc}
\hline Variabel & Koefisien & p-value \\
\hline INTERSEP & 0.0645 & 0.0000 \\
CAR & 0.1580 & 0.0042 \\
NPL & -0.1265 & 0.2053 \\
BOPO & -0.0518 & 0.0000 \\
LDR & -0.0081 & 0.1245 \\
NIM & 0.1819 & 0.0029 \\
GDP & 0.0325 & 0.0237 \\
INF & 0.0335 & 0.1176 \\
\hline N & 150 & \\
$R^{2}$ & 0.4863 & \\
F-stat & 23.8254 & \\
Prob (F-stat) & 0.0000 & \\
\hline
\end{tabular}

Hasil pengujian menunjukkan bahwa NPL tidak berpengaruh terhadap ROA. Hal ini bermakna bahwa peningkatan atau penurunan NPL tidak memengaruhi peningkatan ataupun penurunan ROA. Hasil penelitian ini mendukung Kosmidou (2008) yang menyatakan bahwa NPL tidak berpengaruh terhadap perubahan laba bank. Risiko usaha bank yang tercermin dalam NPL tidak berpengaruh terhadap ROA. Hasil penelitian menyatakan bahwa tingkat NPL dari sampel masih tergolong rendah, yaitu di bawah $5 \%$. Bank selalu menjaga agar besarnya NPL berada di bawah 5\%. Hal ini dikonfirmasi dengan rata-rata NPL di bawah 5\% (sebesar 2.83\%). Walaupun rata-rata NPL di bawah 5\%, namun terdapat bank dalam sampel yang memiliki NPL di atas $5 \%$ pada suatu periode. Hasil regresi membuktikan bahwa BOPO berpengaruh negatif dan signifikan terhadap ROA. Peningkatan BOPO dapat berdampak pada penurunan ROA, dan sebaliknya. Hal ini mengisyaratkan bahwa semakin efisien bank dalam menjalankan kegiatan operasionalnya maka laba yang dihasilkan akan meningkat. Hasil ini mendukung temuan Hayati \& Musdholifah (2014).

Penelitian ini tidak menemukan bukti adanya pengaruh LDR terhadap profitabilitas bank. Peningkatan ataupun penurunan LDR tidak perpengaruh terhadap peningkatan ataupun penurunan ROA. Hasil ini dapat disebabkan karena besarnya pemberian kredit tidak didukung oleh kualitas kredit. Temuan ini mengonfirmasi hasil penelitian Kosmidou (2008) serta Hayati \& Musdholifah (2014). Hasil regresi membuktikan bahwa NIM berpengaruh positif dan signifikan terhadap ROA. Peningkatan NIM berdampak pada peningkatan ROA, dan sebaliknya. Semakin banyak kredit disalurkan, pendapatan bunga akan meningkat dan laba sebelum pajak meningkat. Temuan ini mendukung Hayati \& Musdholifah (2014) yang menyatakan bahwa NIM berpengaruh positif dan signifikan terhadap ROA.

GDP berhubungan positif dan signifikan terhadap ROA. Hal ini bermakna bahwa GDP yang semakin meningkat berdampak pada ROA yang semakin meningkat pula. Keadaan ekonomi yang semakin membaik yang ditandai dengan pertumbuhan positif GDP membuat 
bank mencapai efisiensi dalam menghasilkan laba. Temuan ini konsisten dengan Kosmidou (2008) serta Lee \& Kim (2013).

Hasil penelitian menunjukkan bahwa inflasi tidak berpengaruh terhadap ROA. Hasil ini tidak sesuai dengan Putong (2010) yang menyatakan bahwa inflasi yang tinggi menyebabkan masyarakat cenderung menarik tabungan sehingga banyak bank yang kekurangan dana. Pernyataan ini juga didukung oleh Horne \& Wachowicz (2012) menyebutkan bahwa laju inflasi yang tinggi dan tidak terkontrol dapat menganggu bank dalam upaya pengerahan dana, sehingga inflasi yang tinggi akan mengurangi jumlah perolehan dana perbankan. Penelitian ini tidak dapat menunjukkan apakah inflasi diantisipasi atau tidak oleh bank. Hasil penelitian ini tidak konsisten dengan Kosmidou (2008).

Nilai $\mathrm{R}^{2}$ sebesar $48.63 \%$ menunjukkan bahwa seluruh variabel independen (CAR, NPL, BOPO, LDR, NIM, GDP, dan INF) dapat menjelaskan variabel dependen (ROA) sebesar 48.63\%. Sedangkan sisanya sebesar $51.37 \%$ dijelaskan oleh variabel lain di luar model penelitian. Hasil penelitian menunjukkan bahwa CAR, NPL, BOPO, LDR, NIM, GDP, dan INF secara bersama-sama berpengaruh signifikan terhadap ROA.

\section{SIMPULAN}

Hasil penelitian menunjukkan bahwa capital adequacy ratio (CAR), net interest margin (NIM), dan GDP berpengaruh positif dan signifikan terhadap return on assets (ROA). Beban operasional terhadap pendapatan operasional berpengaruh negatif dan signifikan terhadap return on assets (ROA). Non performing loan (NPL), loan to deposit ratio ( $L D R$ ), dan tingkat inflasi tidak berpengaruh terhadap return on assets. Implikasi dari penelitian ini adalah sektor perbankan harus selalu menjaga kinerja perusahaan dengan memperhatikan faktor internal dan eksternal. Hasil penelitian juga berimplikasi pada investor dan masyarakat untuk lebih teliti dalam pengambilan keputusan untuk berinvestasi maupun menyimpan dana pada bank.

Terdapat beberapa rekomendasi yang dapat dijadikan pertimbangan untuk penelitian sejenis di periode mendatang. Pertama, penelitian mendatang dapat menambah variabel penelitian lain yang berpengaruh terhadap profitabilitas bank agar diperoleh hasil yang lebih akurat. Kedua, penelitian selanjutnya dapat menambah sampel penelitian dengan menggunakan bank umum yang tidak terdaftar di Bursa Efek Indonesia untuk melihat apakah terdapat perbedaan faktor-faktor penentu profitabilitas bagi bank umum yang terdaftar atau tidak terdaftar di Bursa Efek Indonesia.

\section{PUSTAKA ACUAN}

Anbar, A., \& Alper, D. (2011). Bank Specific and Macroeconomic Determinants of Commercial Bank Profitability: Empirical Evidence from Turkey. Business and Economics Research Journal. Vol. 2, No. 2: 139-152.

Flamini, V., McDonald, C. \& Schumacher, L. (2009). The Determinants of Commercial Bank Profitability in Sub-Saharan Africa. IMF Working Paper 09/15. Washington D.C: International Monetary Fund.

Hanafi, M. M. \& Halim, A. (2016). Analisis Laporan Keuangan. Yogyakarta: UPP STIM YKPN. 
Hayati, N., \& Musdholifah. (2014). Determinan Profitabilitas Perbankan Nasional di Indonesia. Jurnal Bisnis, Manajemen \& Perbankan. Vol. 1 (1): 77-96.

Horne, J. C. V. \& Wachowicz, J. M. (2012). Prinsip-prinsip Manajemen Keuangan (Edisi 13). Jakarta: Salemba Empat.

Javaid, S., Anwar, J., Zaman, K., Gafoor, A. (2011). Determinants of Bank Profitability in Pakistan: Internal Factor Analysis. Mediterranean Journal of Social Sciences. Vol. 2 (1): 59-78.

Kosmidou, K. (2008). The Determinants of Banks' Profits in Greece during the Period of EU Financial Integration. Managerial Finance. Vol. 34 (3): 146-159.

Lee, J. Y. \& Kim, D. (2013). Bank Performance and Its Determinants in Korea. Japan and the World Economy. Vol. 27 (1): 83-94.

Nachrowi, N. D. \& Usman, H. (2006). Pendekatan Populer dan Praktis Ekonometrika untuk Analisis Ekonomi dan Keungan. Jakarta: LPFE-Universitas Indonesia.

Petria, N., Capraru, B., \& Ihnatov, I. (2015). Determinants of Banks' Profitability: Evidence from EU 27 Banking Systems. Procedia Economics and Finance. Vol. 20: 518-524.

Putong, I. (2010). Economics: Pengantar Mikro dan Makro (Edisi 4). Jakarta: Mitra Wacana Media.

Sufian, F. \& Chong, R. R. (2008). Determinants of Bank Profitability in a Developing Economy: Empirical Evidence from the Philippines. Asian Academy of Management Journal of Accounting and Finance. Vol. 4 (2): 91-112.

Taswan. (2010). Manajemen Perbankan (Edisi 2). Yogyakarta: UPP STIM YKPN. 